\title{
Collective Motherliness in Italy. Reception and Reformulation of Ellen Key's feminist ideas in Sibilla Aleramo and Ada Negri (1905-1921)
}

\author{
Ulla Åkerström (Dept of Languages and Literatures - University of \\ Gothenburg, Sweden)
}

\begin{abstract}
This paper aims to explore how the Swedish writer Ellen Key's ideas on collective motherliness and on the relationship between man and woman were received and reformulated in the articles, poetry and prose of Sibilla Aleramo and Ada Negri before and after the First World War. The ideas in Aleramo's autobiographical novel Una donna (1906) were close to Key's theories, but her autobiographical novel Il passaggio (1919) was quite different. Ada Negri's idealistic view of motherhood, as expressed in her collection of poetry Maternità (1904), corresponded to parts of Key's conception of motherhood, while Negri's dream of single motherhood and the realisation of that ideal is emphasized in her autobiographical novel Stella mattutina (1921).
\end{abstract}

Keywords: Collective motherliness, Ellen Key, Sibilla Aleramo, Ada Negri, feminism

\section{Introduction}

Ellen Key (1849-1926) was one of Sweden's most internationally renowned thinkers during her lifetime, and she was influential in many European countries. A starting point for this article is the hypothetical notion that Ellen Key's concept of collective motherliness worked as a bridge between tradition and modernity for feminists in Italy and Spain. ${ }^{1}$ In Key's thinking, collective motherliness implies something more than biological motherhood; it is the result of a process when woman completes herself according to her "true essence", turning natural motherliness into collective motherliness: a cultural and political force with the power to improve society. For Key, biological motherhood was not a prerequisite for becoming a collective mother. Rather, collective motherliness was an argument for women's right to vote and to participate actively in politics, as women's maternal force was expected to change society in a positive direction, entailing new approaches and new priorities.

The most vivid period regarding the interest for Ellen Key's ideas in Italy coincides more or less with her long sojourns there during the first decade of the 20th century. During that period and until the beginning of the First World War, she was being discussed in the press and in periodicals by several Italian intellectuals, both in a positive and negative way.

\footnotetext{
${ }^{1}$ This article is part of a project funded by the Swedish Research Council about the reception and reformulation of Ellen Key's ideas in Italy and Spain. Ulla Åkerström's text is oriented towards Italy, and Elena Lindholm's text towards Spain.
} 
The purpose of this paper is to explore how her work and ideas on collective motherliness and how the relationship between man and woman were received and reformulated in the articles, poetry and prose of two Italian writers before and after the First World War. The writers are Sibilla Aleramo, whose real name was Rina Faccio (1876-1960), and Ada Negri (1870-1945). We will show how close the ideas in Aleramo's autobiographical novel Una donna (1906) were to Key's theories, as well as how Key expressed herself in the novel and its content. In contrast, we will see how the autobiographical novel Il passaggio (1919) differed from Una donna. Furthermore, we will demonstrate how Ada Negri's idealistic view of motherhood, as expressed in her collection of poetry Maternità (1904), corresponded to parts of Key's conception of motherhood. Lastly, we will explore Negri's dream of single motherhood and the realisation of that ideal in the image of the mother in the Negri's autobiographical novel Stella mattutina (1921).

In Italy, there has been a strong mother cult for many centuries with Mary, mother of Jesus, as a central figure. The strong mother figure is still today a part of the most common stereotype in popular culture associated with Italy. The importance of motherhood was also dominating in the Italian women's movement from the 1890 s to the $1920 \mathrm{~s}$. After that, fascism glorified the role of the mother in the nation's name, reproducing the 19th century ideal of her as the angelo del focolare (angel of the hearth). In the 1890s, the movement of women's emancipation assumed more organised forms in Italy. Previously, it had been led by single groups directed towards the political debate and propaganda, or in a more concrete way through charity and actions directed towards poor women and working women (Buttafuoco 1991, 178-179). These directions represented the two ways of thinking and acting of the emancipation movement in Italy and in other European countries (Buttafuoco 1988, 167). One direction aimed at equality between the sexes with a gender-neutral interpretation of civil rights. The other direction was also certainly in favour of legal and social equality but meant at the same time that there were fundamental differences between men and women and that women had special qualities that were identified in female experiences. This point of view is often today identified as difference feminism. It was this direction that had most followers in Italy, later developing into the social feminism, also called practical feminism, which aimed at creating female citizens, not only citizens who happened to be women.

The quality that most distinguished the difference between women and men was motherhood, both as a reproductive capacity and as a value-creating force. At the turn of the last century, this view was common in Western feminism, when feminists tried to resolve the "dilemma" that motherhood implied for them (Allen 2005). Ersilia Bronzini Majno (18591933) was one of the most prominent figures of the practical feminism in Milan in the late 19th and early 20th centuries. She was urged by a strong philanthropic interest and founded the association Unione Femminile Nazionale in 1899 (Gaballo 2015). The first program manifesto included education, social institutions and protection for mothers and children. Ellen Key's concept of collective motherliness was close to the notions of the Italian practical feminists, and they nurtured a vivid interest for her. It is in these circles that one finds the interpretative community that was interested in Ellen Key's ideas, mainly as they were expressed in The Century of the Child (translated to Italian in 1906) and Love and marriage (translated to Italian in 1909). In this context, Stanley Fish's concept of interpretative communities is used as a way of understanding how the reception and reformulation of texts work in a collective production of meaning (Fish 1982, 13-17). In the interpretative community around Ersilia Majno, there were writers like Sibilla Aleramo and Ada Negri, who 
in different ways, both treated the question of maternity and the relationship between man and woman. Negri was among Majno's collaborators and co-founder of the Unione Femminile. Already in the 1890's, Aleramo was engaged in practical feminism, and her social work continued after her having left her husband and son (Moretti 2014, 40). Moretti contends that Aleramo was the one who inspired Maria Montessori to what she calls social motherhood, a concept that is not identical to Ellen Key's collective motherliness, but very near to it. It was during this social work that Aleramo met Maria Montessori. According to Moretti, it was Aleramo who influenced Montessori to the social motherhood (Moretti 2014, 40). The question of the relationship between Key and Montessori is too complicated to be discussed in this article, but it is certain that both of them belonged to the same interpretative community in Italy.

\section{Sibilla Aleramo (1905-1907)}

In fact, it was Sibilla Aleramo (1876-1960) who presented Ellen Key to the Italian public, probably for the first time, in the journal Nuova Antologia in 1905. As is well known, Aleramo had experienced an unhappy marriage and the subsequent separation; as such, she was very interested in the Swedish writer's ideas about love and marriage. In Nuova Antologia, Aleramo (using the name Nemi) made a presentation of Key based on an article in the French journal La Quinzaine by Marc Hélys (pseudonym of Marie Léra). In her article, Aleramo describes Sweden as "one of the countries where the women's emancipation movement was accentuated". 2 She then confronts Ellen Key with another famous Swedish female writer, Selma Lagerlöf, saying that Key "now contests her for the primacy of the public's admiration". Furthermore, she tentatively claims that Key's work is more interesting than that of Lagerlöf since it is "more alive and present, more symptomatic and documentary of the psychological evolution which is maturing" in their country (Aleramo 1905). Aleramo mentions the right to maternity or motherhood as a fundamental base in the thought of Ellen Key, as well as the idea that the child "should be a product of love, of a great love, and in the search of it even a whole life will not appear too long" (Aleramo 1905).

In 1906, Sibilla Aleramo wrote again about Ellen Key in Nuova Antologia, this time presenting Key's book The Century of the Child, published in Italian that year. She finds it "the expression of one of the strongest contemporary female intellects" (Aleramo 1906). Her admiration is apparent. It is not strange that Sibilla Aleramo reacted with such appraisal to the words of Key, considering her own experiences and feminist ideas. Sibilla Aleramo saw the Swedish writer as a model and as an authority. In particular, Ellen Key's emphasis on the right to motherhood was something that appealed strongly to Sibilla Aleramo, who had been forced to sacrifice her own motherhood when she left her husband and young son to live her life as a free woman. As she narrates in the last chapter of Una donna, she never meant to leave her son but had hoped to get custody of him after the separation. Instead, her husband, who had the law on his side, refused to accept a similar situation and forbade mother and child to meet. In June 1907, Sibilla Aleramo published an article in the newspaper La Tribuna about Ellen Key, who by then had become her friend. In the article, Sibilla Aleramo almost glorifies Key, describing her as a person with a "simple, energic eloquence" (Aleramo 1907) who arouses enthusiasm at her speeches. Aleramo mentions the two conferences that Key, by invitation of the Unione Femminile Nazionale, had held in Milan and Turin earlier that year.

\footnotetext{
${ }^{2}$ All translations from Italian in this article are the author's unless otherwise specified.
} 
According to Aleramo, The Century of the Child, a book with ideas that she finds revolutionary, had not been discussed enough in Italy, nor fully understood.

At the end of 1906, Sibilla Aleramo's autobiographical novel Una donna was published, according to Moretti, "one of the first accounts of social mothers in Italy" (Moretti 2014, 38). The novel is nowadays regarded as a feminist classic and has been widely studied since the 1970's when it was rediscovered by the second wave of the Italian feminist movement. The story of the novel, based on Aleramo's own experiences, is well-known. It is told in the first person and narrates the protagonist's family's move from Northern Italy to a small place in the South where her father was in charge of a factory. It also describes her own working experience there and the seduction by a young man, an experience that is often interpreted as rape, the subsequent marriage and the birth of a much-loved son. Eventually, the husband reveals himself to be a brute, and after much suffering, she leaves him, for fear of repeating the marriage of her parents, which had led to her mother's suicide attempt and ending up in an asylum. In the narration, there is an evident criticism towards society and the unjust laws that gave the husband every right and the wife none. Furthermore, the novel discusses maternity, asking why it has been linked to sacrifice for so many centuries. Una donna is indeed to be seen not only as a description of her martyrdom as a wife but also as an explanation to her son as to why she had left him and by extension, an interpretation of how she was denied the right to motherhood. Aleramo's way into the feminist interpretative community is also fictionalized in the book, when she describes her work with the fictive female magazine Mulier in Rome (Aleramo 1988, 136). In the book, the person she calls Mother of the Poor, an old Mazzinian woman, is described as a representative of the practical feminism (Moretti 2014, 39). This woman introduces the narrator of Una donna to the social work, in which Sibilla Aleramo was actually engaged in after her separation, together with her new partner Giovanni Cena.

When Ellen Key was in Rome in April 1907, Sibilla Aleramo contacted her, and they became friends. Key eventually left Rome, and they remained in contact by letter. In June the same year, Key sent a letter to Aleramo in which she writes about a discussion she has had with Ersilia Majno, a mutual friend of theirs (Åkerström 2012, 65). Some years earlier, in 1903, Aleramo had sent a draft of her autobiographical novel to Majno, asking for her opinion. This draft provoked a conflict between Majno and Aleramo, due to their different visions of the female role as mother and of the relationship between man and woman. As Scamaruzza observes, the conflict depended not only by a personal disagreement but also on a generational one (Scaramuzza 2007, 116). For both of them, the question of maternity was central, but it was viewed in two completely different ways. Majno was also against the revelation of personal experiences and the faith of Aleramo that she would find happiness with another man. In fact, Sibilla Aleramo at the beginning was supported by many other female friends and acquaintances regarding her choice to leave her husband, until they realised that she had had a relationship first with the poet Felice Damiani, and then with Giovanni Cena (Scaramuzza 2007, 102-103). During the meeting with Majno in June 1907, Key seems to have tried to explain the situation and Aleramo's choices to Majno, even though she had not yet read Una donna. She also referred to Ada Negri, who had talked to Majno in the same way (Åkerström 2012, 65).

In July the same year, Key had finally read Una donna, and she wrote a letter to Aleramo about her impressions and thoughts (Åkerström 2012, 72-73). Previously, Key had written in Love and marriage about the ideal relationship between man and woman, based on 
love and mutual understanding, and also about divorce, which she found just if the spouses did not live in perfect harmony. With this in mind, one would have thought that she would have been in favour of the choices of Aleramo's protagonist (and alter ego) in Una donna. Key, in contrast, however, demonstrated a considerable dose of scepticism, saying that the novel's protagonist had not done the most possible to save the union with the husband. Key continued by stating that everything precipitated in the third (and last) part of the novel and that the reasons given by the protagonist to explain her choices were not sufficient. She should have done more, according to Key, for example by proposing some kind of pact to the husband which would have permitted her to remain in their home without having to accept marital relations. She should also have tried to obtain a legal separation before escaping. It is indeed surprising that Ellen Key in her letter proposed a solution which she, according to her own words in Love and marriage, would have considered very unfortunate, exemplified by: "Thus for one or both of the parties a marriage that is persisted in without the love of one or both causes profound suffering either through this humiliation or through lifelong celibacy" (Key 1911, 294). It is evident that in front of a concrete case like Aleramo's not even Ellen Key, considering the strong bond between mother and child, was convinced that it was the best solution for the woman to abandon the family. Key was not totally convinced by the reasons given in the novel, but since she had taken a great liking to her young friend, she, therefore, wrote that she had understood everything. Key asserted that her criticism only regarded the novel, where she would have liked more clarity in the description of the psychology of the protagonist. One can speculate about the reaction of Key, who contradicts the theories that she had proposed in her own texts. Apparently, in front of a case from real life, she partially felt the need to revise her position regarding a marriage with a child, where there was clearly an innocent victim. Between the lines, there is a critique quite similar to that of other women against Una donna, who had turned against the fact that the child was abandoned, which is at the same time an indirect critique against the choices of Aleramo herself. However, Ellen Key never openly accused her friend of this, partly because she did not want to offend her, and partly because she did not want to reject her own theory regarding marriage. When Aleramo some days later answered Key's letter, she was full of gratitude and compliance in front of the older friend's opinion (Åkerström 2012, 73-74). She does not show if she was hurt. On the contrary, she writes that she is happy, even if she tries to defend her novel, saying that she may make some adjustments in a future Italian edition or in the translations into other languages, to make sure that the readers understand her message better. Even if Ellen Key during her meeting with Ersilia Majno had tried to defend Aleramo's choices, her reactions towards the novel and later her sad reactions towards the breaking up between Aleramo and Giovanni Cena, show that Key probably was nearer to Majno's ideas than to Aleramo's. Indeed Key was part of an older generation (she was ten years older than Majno), and even if she often was presented as "the apostle of free love", she was quite conservative regarding real cases like Aleramo's and other similar ones.

In May 1907, Ellen Key had held a lecture in Turin and Milan, which was afterwards published as an article in Vita Femminile Italiana, the journal of the Unione Femminile (Key 1907). The article contained a kind of summary of Ellen Key's ideas regarding motherhood and the relationship between men and women. The Italian contemporary interest for her, with great certainty, originated from these ideas and formed the image of her among Italian feminists. When Ellen Key in 1908 was invited by Ersilia Majno as honorary president at the women's congress in Milan organized by the Unione Femminile, she was seen in Italian feminist circles as a point of reference at an international level in the debate regarding women 
and motherhood (Pironi 2010, 73). During the congress, Ersilia Majno talked about children's rights and expressed the opinion that all mothers should have the right to have custody of their children and to carry out their duties as parents. Furthermore, she opinionated that there is no such thing as an illegitimate motherhood (Unione femminile 1909, 353). In this, Majno showed how close her opinions were to Key's ideas. Sibilla Aleramo was supposed to come to this Congress, but never actually showed up. Ada Negri, who had been appointed as president of the Congress together with Key, fell ill and was replaced by Ersilia Majno.

\section{Ada Negri (1904-1911)}

The poet Ada Negri had very strong feelings regarding maternity and its importance for women. However, the poems in Negri's collection Maternità (1904) are far from Ellen Key's thoughts about collective motherliness. Maternità was published after the birth of Negri's daughter Bianca, who was to become a great inspiration for Negri's poetry. The collection treats various aspects of motherhood with a strain of mysticism, in a sad thematic with suffering or dying mothers and dying or abandoned children. Gambaro postulates that the female figures in Maternità are suffering creatures who are doomed to defeat, with the exception of the io poetante, the poet who in the first person sings motherhood's praises (Gambaro 2010, 49). Amoia points out that the poems demonstrate how deeply the women in emancipated circles were influenced by the mother cult; furthermore, she suggests that some of them may have been seen as old-fashioned by their contemporaries (Amoia 2000, 66-67).

The poems in Maternità thus take place at a completely different level in respect to the political and social reality, and they are far from the ideas regarding collective motherliness. That said, Negri and Key do have a point in common: the mystification of motherhood that sometimes recurs also in Key. In the aforementioned article in Vita Femminile Italiana, Ellen Key talked about the value of motherhood in Western civilisation from the mothers of Spartans and Romans and onwards, brought on to modern times via the Catholic church and its cult of Mary, up to poets as Ada Negri and Giovanni Cena. Key had been interested in the cult of Mary for many years, and she constantly returned to it in her writings, meaning that it contained thoughts of women's vital task to build the family and to have the education of humanity as a life purpose. She had developed these thoughts since 1875 , when her article "The Cult of Mary of Protestantism" was published. The family is a deeply founded unity according to Key. It represents God's thought in the Creation, and it is this essence that Protestantism has manifested. It meant that every woman who in "chastity and piety foster the purpose of the family" is a holy virgin, and it is in this context that one must understand the expression 'the cult of Mary of Protestantism' (Key 1875). In Love and marriage, Ellen Key returns to the cult of Mary, saying that the Latin nations render a homage to woman and that "it expressed through the cult of Mary its reverence for what is deepest in woman, motherhood" (Key 1911, 58). The cult of Mary became in some ways the expression of the female ideal for Ellen Key, an ideal that coincided with Ada Negri's idealizing mother cult. Even if Ada Negri's Maternità was published before Ellen Key became famous in Italy, the similarities in their ideas were certainly of importance in the subsequent contacts between them.

That Ada Negri took part of Ellen Key's ideas, is demonstrated in an article she wrote for the Florentine journal Il Marzocco in 1911 (Negri, 2011a). In the article, entitled "A child" (in the meaning of son or daughter), Negri writes about motherhood meaning that all women 
(or "honourable" women, more precisely), should have the opportunity to become mothers. She describes a meeting she once had with a female teacher, who had expressed the sorrow she felt about not having the possibility to have a child of her own. This meeting had made Negri reflect over unmarried women and motherhood. In the article, Negri discusses the injustice that laws and customs deny unmarried, independent women who provide for themselves, to have a child of their own. Why should she, who is educated, judicious, experienced and used to fighting and thus very apt to raise a child, have to settle for loving and educating only other people's children? The question of the father is not discussed by Ada Negri more than her declaring that there are already so many fatherless children in the world. At the same time, she points out that she is not against marriage and that the ideal is a legitimate relation between a man and a woman who love each other. In this context, she cites Ellen Key and her idea of the ideal union, which Key, in the interpretation of Negri, "recognises as the only one worthy to sanctify the marital bonds" (Negri 1911a). Unfortunately, this occurs too seldom, writes Negri. Therefore women should be allowed to become mothers, even if they fail to obtain the "perfect union". In an article some weeks later in the same journal, Ada Negri follows up and develops her arguments, as a response to all the reactions, positive and negative, that she has had on her first article (Negri 1911b). In both texts, it is clear how Ada Negri has taken in Ellen Key's reasoning regarding love and marriage and adapted it to her own view on the matter.

\section{Aleramo and Negri after the Great War (1919-1921)}

During and after the First World War, Ellen Key was mentioned more sporadically in the Italian debate. Still, many of the writers and other intellectuals who earlier had been inspired by her in one way or another, continued to write and to publish. Sibilla Aleramo and Ada Negri both wrote novels in the genre often defined as autofiction, with texts based on their own lives, Aleramo with Il passaggio (1919) and Negri with Stella mattutina (1921). Il passaggio is quite different from Aleramo's previous novel Una donna. After the first decade of the new century, which for Aleramo had been an intense period of participation within the practical feminism and with philanthropic work, Sibilla Aleramo distanced herself from the feminist movement, turning to a more "spiritual" feminism (Scaramuzza 2007, 205). Around 1911, she thus went from being a feminist writer (scrittrice femminista) to becoming a female writer (scrittrice femminile) (Scaramuzza 2007, 211), as a result of the changing society, but also because of her personal life. After having ended the long relationship with Giovanni Cena, and the shorter one with Lina Poletti, her "second life" started with the long list of lovers which became a characteristic for her. She started to write Il passaggio in 1912 and finished it in 1918 (Conti 2000, 98). In a most poetical prose, Aleramo goes back in her narration to 1902, when she was still living with her husband and had a love affair with the young poet Felice Damiani, a relationship that Giovanni Cena later advised her to omit from Una donna. That was, as she puts it in Il passaggio, "perhaps the only concrete sin of my life" (Aleramo 1921, 103). In the book, her love for Damiani, who died in 1904, takes almost mythological proportions. He is described as her true husband, since their love was something completely different from what she had experienced in her legal marriage. Here is the obvious echo of Ellen Key's thought of love as expressed in Love and Marriage. There are other important issues in the book, like Aleramo's suffered motherhood and her love-story with another woman, which are much less consistent with Ellen Key's ideas than those in Una donna. Since Sibilla Aleramo had left the feminist battle and dedicated her life to an 
everlasting search for love, there was not much left in her writings that is reminiscent of her Swedish friend's ideas.

While the question of motherhood in Il passaggio reveals itself only in Aleramo's pain over the lost son, Ada Negri's Stella mattutina is based on the relationship between mother and daughter. At its centre is the girl Dinin, Negri's alter-ego. The novel is told in the third person but from the protagonist's perspective. The female genealogy or matrilinearity that permeates the novel has been noted in the critique (Larco 2015, 166). It starts with Dinin's maternal grandmother, who is a doorkeeper, and with whom Dinin and her mother live, after the death of Dinin's father. When the grandmother dies, mother and daughter live by themselves and the mother works in a factory. Furthermore, the book is dedicated to Negri's daughter Bianca, which adds another generation to the line (Mazzoni 1997, 59). Critics (Larco 2015, 176; Mazzoni 1997, 59; Pickering-Iazzi 1994, 182) claim that the representation of motherhood in Stella mattutina in many ways goes beyond the old patriarchal ideal image of woman as a wife and mother. Ada Negri has created a new motherly figure which no longer is passively self-erasing. Instead, she is a strong woman who works and creates possibilities for her daughter to study, without becoming a martyr. Negri re-elaborates and reformulates the ideal image of the mother, without reproducing the cliché of the passive, self-sacrificing angel of the mother-cult. Instead, the mother is depicted as an intelligent and active woman who chooses to live without a husband, transgressing the patriarchal model of woman as mother (Pickering-Iazzi 1994, 182). This ideal figure can be interpreted as a free reformulation of Ellen Key's motherly ideals, nearer to the single mother figure Negri dreamt of in her articles in Il Marzocco several years earlier. Such a reading of Negri's novel could suggest that Negri was a feminist writer, but it is not possible to define her in that way, neither in her poetry nor in her prose, even if she concentrates on female figures. Her vision of women's condition in society is pessimistic. For her, the roads to emancipation through work and economy which had opened to bourgeois women during the first decades of the 20th century was only a deception and only a more sophisticated form of oppression (Gambaro 2010, 185). Ada Negri had a problematic and contradictory attitude towards women's and mothers' position in society and in the home, as well as towards men and their part in reproduction. She seemed to dream of childbearing without the interference of men, in a sort of virginal procreation, and had basically a negative perception of the relationship between man and woman.

\section{Conclusions}

Sibilla Aleramo and Ada Negri are examples of how differently Ellen Key's ideas could be perceived and reformulated in Italy, even if the two writers belonged to the same interpretative community. Whereas the ideas in Aleramo's Una donna were closer to Key's theories, Il passaggio was completely different. Ada Negri's elevation of motherhood as something almost holy, corresponded to parts of Key's conception of motherhood, but lacked the social impact that the concept of collective motherhood implied. On the other hand, the image of the ideal mother as depicted in Negri's Stella mattutina is more concrete than the mother figures in Maternità. While Aleramo sought for acknowledgement regarding her own experiences as a woman and a mother, Negri concentrated on motherhood as a mythical and almost holy experience for women. Ellen Key's ideas of collective motherliness as central in the creation of a new society is not apparent in the texts of either Aleramo, or Negri. Still, since both of them were active within practical feminism, their understanding of collective motherliness took concrete ways of reformulation in their social work. 


\section{References}

Åkerström, Ulla. 2012. Cara grande amica. Il carteggio Ellen Key-Sibilla Aleramo. Roma: Aracne.

Aleramo Sibilla. [Nemi]. 1905. "Ellen Key.” Nuova Antologia, October 1, 1905.

Aleramo Sibilla. [Nemi]. 1906. "Il secolo dei fanciulli." Nuova Antologia, June 1, 1906.

Aleramo Sibilla. 1921. [1919]. Il passaggio. Firenze: Bemporad.

Aleramo, Sibilla. 1988. Una donna. Milano: Feltrinelli.

Aleramo Sibilla. 1907. “La donna dell'avvenire. Ellen Key.” La Tribuna, June 30, 1907.

Allen, Ann Taylor. 2005. Feminism and Motherhood in Western Europe 1890-1970. The Maternal dilemma. New York: Palgrave Macmillan.

Amoia, Alba, 2000. No Mothers We! Italian Women Writers and Their Revolt Against Maternity. Maryland: Oxford University Press of America.

Buttafuoco, Annarita. 1991. "Motherhood as a political strategy: the role of the Italian women's movement in the creation of the Cassa Nazionale di Maternità." In Maternity and Gender Policies. Women and the Rise of the European Welfare States, 1880s-1950s, edited by Gisela Bock and Pat Thane, 178-195. London and New York; Routledge.

Buttafuoco, Annarita. 1988. "La filantropia come politica. Esperienze dell'emancipazionismo italiano del Novecento." In Ragnetele di rapporti. Patronage e reti di relazione nella storia delle donne, edited by Lucia Ferrante, Maura Palazzi, Gianna Pomata, 166-187. Torino: Rosenberg \& Sellier.

Conti, Bruna. 2000. "Postfazione." In Aleramo, Sibilla. Il passaggio, edited by Bruna Conti, 97-114. Milano: Feltrinelli.

Fish, Stanley. 1980. Is There a Text in This Class? The Authority of Interpretative Communities. Cambridge, Massachusetts: Havard University Press.

Gaballo, Graziella. 2015. Il nostro dovere. L'Unione Femminile tra impegno sociale, guerra e fascismo (1899-1939). Novi Ligure: Edizioni Joker.

Gambaro, Elisa. 2010. Il protagonismo femminile nell'opera di Ada Negri. Milano: LED Edizioni Universitarie.

Key, Ellen. 1900. Barnets århundrade. Stockholm: Albert Bonniers förlag.

Key, Ellen. 1903. Kärleken och äktenskapet. Livslinjer I. Stockholm: Albert Bonniers förlag.

Key, Ellen. 1911. Love and Marriage. Translated by Arthur G. Chater. New York and London: G.P. Putnam's Sons.

Key, Ellen. 1907. "La Maternità e la Società.” Vita femminile italiana, fascicolo VII-VIII, July-August, 1907.

Key, Ellen. [unsigned]. 1875. "Litteratur. Protestantismens Maria-Kult." Nya Dagligt Allehanda, May 26, 1875.

Larco, Ioana Raluca. 2015. "(Self)Representations of Motherhood in Ada Negri's Stella mattutina." gender/sexuality/italy, 2. 166-178.

Mazzoni, Cristina. 1997. "Difference, repetition, and the mother-daughter bond in Ada Negri." Rivista di studi italiani, 15(1). 55-74. 
Moretti, Erica. 2014. "Beyond Biological Ties: Sibilla Aleramo, Maria Montessori, and the Construction of Social Motherhood." Italian Culture, vol. XXXII, No. 1, March. 3249.

Negri, Ada. 1904. Maternità. Milano: Fratelli Treves.

Negri, Ada. 1911b. "Per un grido." Il Marzocco no. 9, 26 February, 1911.

Negri, Ada. 1921. Stella mattutina. Milano: Arnoldo Mondadori.

Negri, Ada. 1911a. "Un figlio.” Il Marzocco, no. 6, 5 February, 1911.

Pickering-Iazzi, Robin. 1994. "The Politics of Gender and Genre in Italian Women's Autobiography of the Interwar Years.” Italica, 71(2). 176-197.

Pironi, Tiziana. 2010. Femminismo ed educazione in età giolittiana. Conflitti e sfide della modernità. Pisa: Edizioni ETS.

Scaramuzza, Emma. 2007. La santa e la spudorata. Alessandrina Ravizza e Sibilla Aleramo. Amicizia, politica e scrittura. Napoli: Liguori editore.

Unione Femminile Nazionale, 1909. Atti del $1^{\circ}$ Congresso Nazionale di attività pratica femminile. Milano 24-28 maggio 1908. Milano: Società Editrice di Coltura Popolare. 